\title{
First record of Paradentalium infractum (Odhner, 1931) (Mollusca, Scaphopoda, Dentaliidae) from the east coast of Venezuela
}

\author{
Caetano, CHS. ${ }^{\mathrm{a} *}$, Garcia, . $^{\mathrm{b}}$ and Lodeiros, CJM. ${ }^{\mathrm{b}}$ \\ aDepartamento de Zoologia, Universidade do Estado do Rio de Janeiro, \\ Av. São Francisco Xavier, 524, Maracanã, CEP 20550-900, Rio de Janeiro, RJ, Brasil

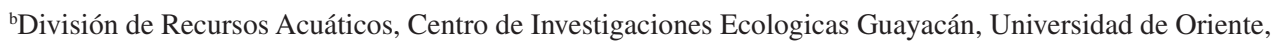 \\ Cumaná, 6101, Venezuela \\ *e-mail: chcaetano@zipmail.com.br
}

Received November 17, 2005 - Accepted June 12, 2006 - Distributed November 30, 2007

(With 9 figures)

\section{Introduction}

Dentalium infractum was described by Odhner (1931) from the abundant malacological material collected by Swedish Antarctic Expedition, station 1, 3300' S and $51^{\circ} 10^{\prime} \mathrm{W}$, at $80 \mathrm{~m}$. As observed by Scarabino (1973: 193), the geographical coordinates given in the original description corresponds, in fact, to southern Brazil and not from Uruguay as stated by Odhner (1931). Scarabino (1973) recorded this species from southern Brazil to Uruguay. Subsequently, Penna-Neme (1974) identified specimens of D. infractum from other Brazilian localities: Rio de Janeiro, São Paulo, Santa Catarina and Rio Grande do Sul. Penna-Neme (1974) also described as a congeneric species, D. elegantulum from Alagoas (10³7-41'S) that Scarabino $(1985,1994)$ synonymized with $D$. infractum thereby extending northwards to the geographical distribution of this species. Scarabino $(1985,1994)$ treated this species as belonging to the genus Antalis and recently, Caetano et al. (2006) transferred this species to Paradentalium.

During 2004, a series of dredgings were carried out off the continental shelf of Venezuela with the aim of characterising the environment of a potential petroleum production area. During these activities, some shells of the scaphopod Paradentalium infractum were obtained from about $22 \mathrm{~m}$ depth in sand-mud bottoms. Here, we present the first record of this species from the coast of Venezuela which constitutes a significant range extension for this species. The studied material was deposited in the molluscs collection of the Departamento de Zoologia, Universidade do Estado do Rio de Janeiro (Col. mol. UERJ).

\subsection{Systematics}

Class Scaphopoda Bronn, 1862

Order Dentaliida Da Costa, 1776

Family Dentaliidae Gray, 1847

Genus Paradentalium Cotton and Godfrey, 1933

Paradentalium infractum (Odhner, 1931)

Figures 1-3

Dentalium infractum Odhner 1931: 1, pl. 1, Figures 1-3, 8, 10, 12, pl. 2, Figures 15-17, 22, 23.
Dentalium (Dentalium) infractum: Scarabino 1973: 195, pl. 1, Figures 2, 2 a.

Dentalium (Antalis) infractum: Penna-Neme 1974: 110, Figures 2, 4, 5, 6.

Dentalium (Antalis) elegantulum Penna-Neme 1974: 108, Figures 1, 3.

Antalis infractum: Scarabino 1985: 198, pl. 72, Figure 1013; 1994: 306, pl. 106, Figure 1501.

Antalis infracta: Steiner and Kabat 2004: 602.

Paradentalium infractum: Caetano et al., 2006: 9, Figures 16-19.

Diagnosis: Shell medium (up to $49 \mathrm{~mm}$ long), slender, regularly and slightly curved, white to yellowish with white opaque bands, polished and shining. Sculptured with six thin primary ribs that disappeared near the central section of the shell and secondary ribs variable in number, remaining parts of the shell surface smooth. Intercostal spaces straight to convex. Apical section hexagonal and oral section circular.

Material examined: Col. mol. UERJ 3708, Venezuela (Gulf of Paria, $09^{\circ} 48^{\prime} \mathrm{N}$ and $62^{\circ} 11^{\prime} \mathrm{W}$ ), 5 empty shells, 22 meters, ix.2004.

Distribution: Venezuela (present paper); Brazil: Alagoas, Bahia to Rio Grande do Sul (Odhner, 1931; Penna-Neme, 1974; Scarabino, 1973, 1975, 1985, 1994); Uruguay: off Rio de la Plata (Scarabino, 1973). Living 40-190 m, empty shells 5 to $269 \mathrm{~m}$.

Remarks: Antalis cerata and Paradentalium disparile are the most similar species to $P$. infractum in the western Atlantic. Paradentalium infractum and A. cerata (Figures 7-9) shared the pattern of alternating sculptured and smooth portions along the shell but the latter species has an apex with nine to twelve ribs whereas $P$. infractum has a hexagonal apical section (Figure 2). Further, $A$. cerata has a microscopic reticulation in the intercostal spaces (Figure 9). The apex consists of six ribs in both $P$. disparile (Figure 5) and P. infractum (Figure 2) but in $P$. disparile the secondary ribs are more numerous and stronger occurring over the entire shell, so that $P$. disparile has no smooth portions on the shell surface. 

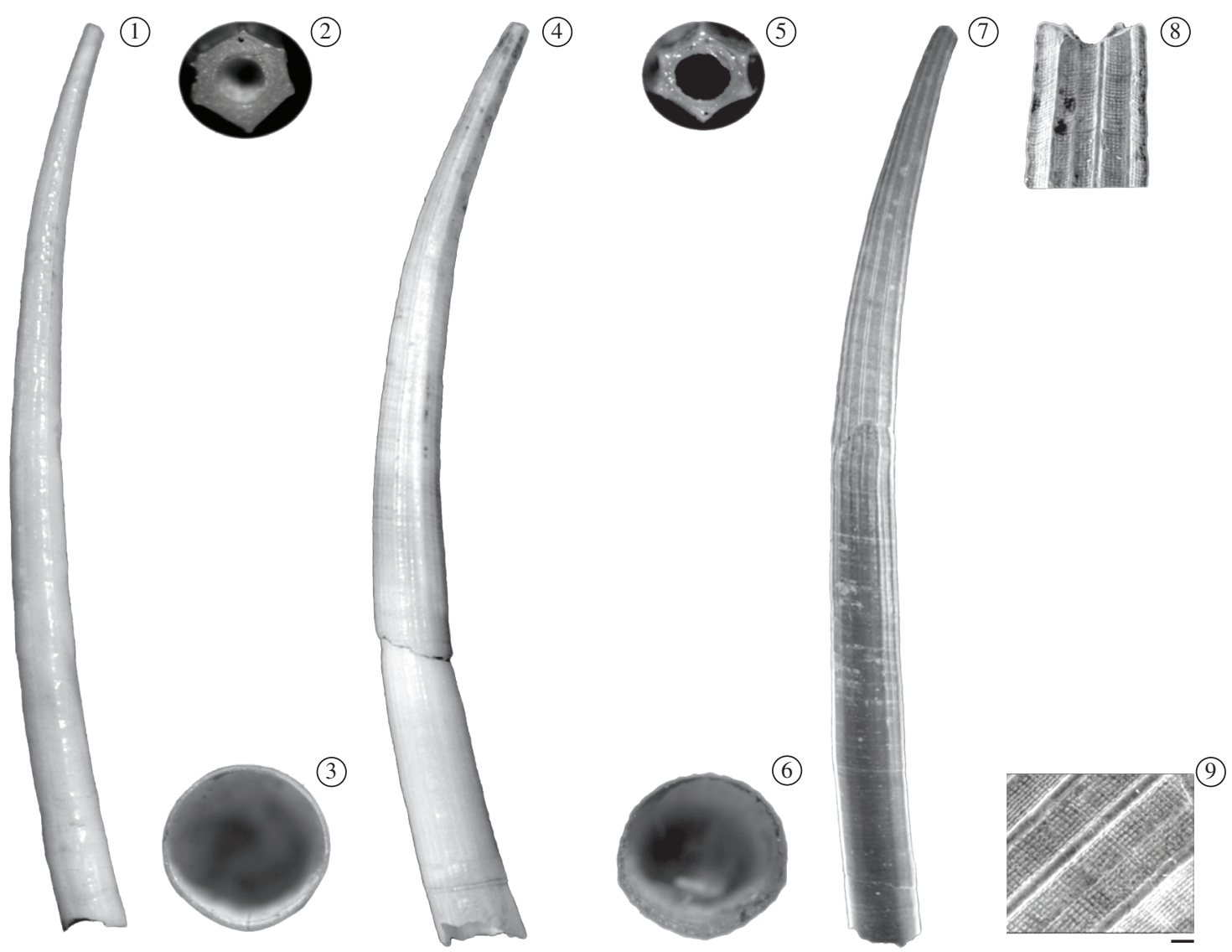

Figures 1-9. 1-3) Paradentalium infractum, Col. mol. UERJ 3708, Venezuela, Gulf of Paria, $09^{\circ} 48^{\prime} \mathrm{N}$ and $62^{\circ} 11^{\prime} \mathrm{W}, 22 \mathrm{~m}$, shell length: 28 mm; 4-6) Paradentalium disparile, Col. mol. UERJ 3791, from the same locality as for P. infractum, shell length: 29 mm; 7-9) Antalis cerata, IBUFRJ 14253 (Col. Moluscos, Departamento Zoologia, Universidade Federal do Rio de Janeiro), Brazil, $18^{\circ} 58^{\prime}$ 53” S and 37 51'06” W, $247 \mathrm{~m}$, shell length: $27 \mathrm{~mm}$. Scale bars: $100 \mu \mathrm{m}$.

Paradentalium infractum was long considered to be a cold-water species being recorded from Rio de Janeiro, Brazil to Rio de la Plata, Uruguay. The records from Alagoas, north Brazil and from Venezuela (present paper) indicate a wider geographical distribution such as that observed in other Western Atlantic scaphopod species, e.g., Polyschides tetraschistus occurs from North Carolina, USA to Argentina.

Acknowledgments - The authors express their deepest gratitude to Dr. Victor Scarabino (Muséum national d'Histoire naturelle), Dr. Ricardo Silva Absalão (UERJ/UFRJ) and one anonymous reviewer for a critical reading and valuable suggestions of the final manuscript.

\section{References}

CAETANO, CHS., SCARABINO, V. and ABSALÃO, RS., 2006. Scaphopoda (Mollusca) from the Brazilian continental shelf and upper slope $\left(13^{\circ}\right.$ to $\left.21^{\circ} \mathrm{S}\right)$ with descriptions of two new species of the genus Cadulus Philippi, 1844. Zootaxa, vol. 1267, p. 1-47.
ODHNER, NH., 1931. Die Scaphopoden. Further Zoological Results of the Swedish Antarctic Expedition 1901-1904, vol. 2, no. 5, p. 1-8.

PENNA-NEME, L., 1974. Considerações sobre os Scaphopoda (Mollusca) da costa brasileira, com descrição de uma nova espécie. Pap. Avulsos Zool., vol. 28, no. 6, p. 105-126.

SCARABINO, V., 1973. Scaphopoda del sur del Brasil, Uruguay y Argentina hasta $42^{\circ} \mathrm{S}$. - (Sistematica, Distribucion). In Anais do V Congresso Latinoamericano de Zoologia. Anais... p. 192-203.

SCARABINO, V., 1975. Class Scaphopoda. In Brazilian Marine Mollusks Iconography. RIOS, EC. Rio Grande, Universidade/ FURG, p. 180-186, pls. 58-59.

-, 1985. Class Scaphopoda. In Seashells of Brazil. RIOS, EC. Rio Grande, Universidade/FURG, p. 196-202, pls. 71-73.

-, 1994. Class Scaphopoda. In Seashells of Brazil. RIOS, EC. $2^{\text {nd }}$ edition. Rio Grande, Universidade/FURG, p. 305-310, pls. 105-107.

STEINER, G., and KABAT, AR., 2004. Catalogue of speciesgroup names of Recent and fossil Scaphopoda (Mollusca). Zoosystema, vol. 26, no. 4, p. 549-726. 